\title{
СУГЕСТИВНІ ВЛАСТИВОСТІ СЛОГАНІВ РЕКЛАМИ БАНКІВСЬКИХ ПОСЛУГ
}

Конюхова Л. І. Сугестивні властивості слоганів банківських послуг.

Проаналізовано сугестивні особливості рекламних текстів, виявлено вербальні лексичні засоби, що мають сугестивне значення, з'ясовано механізм упливу цих засобів на споживача реклами банків. Виявлено, що особливостями сугестії слоганів реклами банківських послуг є використання слів, які здатні навіяти споживачеві думку про престиж і надійність банку та спонукати до дії.

Ключові слова: сугестія, сугестивні властивості, особові займенники, дієслова наказового способу, мовні одиниці з національно-культурним компонентом.

Конюхова Л. И. Суггестивные особенности слоганов рекламы банковских услуг.

Проанализированы суггестивные особенности рекламных текстов, выявлены вербальные лексические средства, имеющие суггестивное значение, и выяснен механизм влияния этих средств на потребителя рекламы банков. Указано, что особенностями суггестии слоганов рекламы банковских услуг есть использование слов, которые могут навеять мысль о престиже и надежности банка и побуждать к действию.

Ключевые слова: суггестия, суггестивные свойства, вербальные средства, интонационные особенности, глаголы повелительного наклонения.

Koniukhova L. I. The suggestive qualities of slogns of banking advertisement.

The suggestive peculiarities of advertising texts are analysed, the verbal means with suggestive meaning are found out, the mechanism of their influence on consumer is explained. The article deals with the suggestive component of advertising. The suggestive peculiarities of advertising texts are analysed, the verbal means with suggestive meaning are found out, the mechanism of their influence on a consumer is explained.

The article states that it is through advertising that the banking sphere tries to attract attention of consumers. This is why the new ways of suggestion are looked for all the time while trying to persuade the consumers that their bank is the unsurpassed one.

The article proves that suggestive meaning is inherent in the words bearing positive information and pointing the social worth of banking services. It is quite often that in the advertising texts we notice adjectives of the highest degree of comparison or the ones that in their semantics perform the meaning of certain "superiority" over the other qualities. They are used to persuade the consumer that what is advertised is the best. Generally, the advertising texts are replete with the attributes helping to call positive associations in a consumer.

The review of advertising slogans showed that advertisers often use linguistic units of the national-cultural component, such as geographical names not related to Ukraine, the names of well-known brands and others.

Our observations have shown that the characteristics of suggestion of banking (с) Л. І. Конюхова, 2016. 
advertising slogans is the use of words that are able to convince the consumer in the prestige and the reliability of the bank. These words are also nouns which name social priorities, imperative verbs that are aiming to induce action, personal and possessive pronouns aimed to "bring" banking institution to the consumer, regional vocabulary.

In most cases analyzed slogans give no clear guidelines, and the words used with the suggestive aim are perceived naturally, they easily fall into the conscious, a person does not take these words for an instruction, people believe that they decide to take advantage of this particular bank themselves. This type of suggestion we call the indirect one. It is organized so that the suggestive information is being provided in a discrete way. This contributes to unconscious, obscure, this contributes unconscious, invisible, spontaneous accepting information. Indirect suggestion is very often involuntary, unconscious. It is a common component of everyday communication. It is hidden, obscure, and therefore it is very suitable for advertising of banks, as preferences and peculiarities of human behavior very often happen to be dictated by the suggestions that are unconscious.

Key words: suggestion, suggestive qualities, personal pronouns, reflexive pronoun, imperative mood verbs, qualifier, language units with national-cultural component.

Сьогодні банки, як відомо, працюють в умовах ринку, тому одним із найважливіших завдань їхньої діяльності є реалізація послуг, які вони пропонують. Метою політики керівництва кожного банку $є$ розширення кліснтури, збільшення сфери збуту, завоювання ринку, зростання отримуваного прибутку. Досягти цієї мети допомагає реклама. Саме за допомогою реклами сучасні банкіри намагаються привернути увагу споживачів й задля цього вишукують все нові й нові способи навіювання думки про те, що тільки їхній банк $є$ неперевершеним у наданні фінансових послуг.

Відомо чимало досліджень, у яких розглянуто шляхи досягнення успіху реклами. Так, М. Сокуленко у праці «Американська технологія створення рекламних текстів» звертає увагу на особливості реклами взагалі та вказує на те, що дієвим засобом іiі впливу на споживача $є$ сугестія, тобто навіювання. Відомий семіолог Р. Барт вказує на те, що маніпулювати свідомістю людей дуже легко, якщо правильно створити» семіологічну систему, яка претендує на те, щоб перетворитися на систему фактів» [2, с. 101]. Львівська дослідниця мови засобів масової інформації Л. Павлюк також переконує в тому, що формувати думку можна за допомогою слів-знаків, слів-символів [3]. Дослідниця мови рекламних текстів Л. М'яснянкіна вважає, що основним чинником ефективності реклами $є$ експресивно забарвлена інформація [4, с. 396]. Н. Фурманкевич зазначає, що слова, використані в рекламному тексті, «накопичують ауру асоціацій» [5, с. 147]. 
Ми ж ставимо за мету вказати на особливості реклами банківських послуг та визначити вербальні сугестивні засоби такої реклами.

Наші спостереження свідчать, що реклама банківських послуг наділена сугестивними особливостями. Простежимо, яка саме лексика переважає в рекламних слоганах банків та визначимо сугестивні властивості використовуваних слів. Наприклад:

IdeaBank пропонує слоган: Ідеальний розпродаж.

Обидва слова цього слогана несуть прийнятну для споживача реклами інформацію: по-перше, люди люблять розпродаж, бо очікують від нього знижок; по-друге, прикметник ідеальний допомагає впевнитися в тому, що ліпшого, ніж пропонує IdeaBank, бути не може.

Внешторгбанк подає такий рекламний слоган: Банківський сервіс найвищого татунку.

Усі слова слогана несуть позитивну інформацію. Приємно сприймається іменник сервіс (обслуговування). Не секрет, що людям узагалі хочеться, щоб їх обслуговували, клієнти очікують від банку якісного обслуговування. Означення найвищий, виражене прикметником найвищого ступеня, допомагає увиразнити позитивні характеристики банківських послуг.

Otpbank пропонує viр-обслуговування та найкращі пропозииіï. Означення vip передає значення престижу, чогось особливого (абревіатура vip має значення «very important person», що в перекладі 3 англійської означає «дуже важлива персона». Слово vip у рекламі вживається у значенні «преміум-класу, елітарне». Означення ж найкращі, виражене прикметником найвищого ступеня порівняння, вказує на неперевершеність банку. А іменник обслуговування, як і сервіс, ніби підкреслює готовність банку служити клієнтові. За допомогою іменника пропозииії банк запевняє, що він не нав'язує своїх послуг, а лише пропонує їх увазі споживача на вибір, виносить їх на розгляд. Така ненав'язливість банку теж викликає довіру до нього.

Як бачимо, означення вказують на цінність і соціальний престиж банківських послуг. Аби переконати споживача в тому, що рекламоване $\epsilon$ найліпшим, рекламісти часто використовують прикметники найвищого ступеня порівняння або такі, що своєю семантикою засвідчують свого роду «вищість» над іншими ознаками. Загалом же рекламні тексти насичені означеннями, які допомагають 
викликати в людини позитивні асоціації.

Навіювати думку про престиж банку допомагають i прислівники, утворені від якісних прикметників. Наприклад, ProCreditBank рекламує ощадну картку та стверджує: Надійно зберігати, зручно купувати.

У слогані реклами цього банку функцію навіювання виконують прислівники зручно, надійно, утворені від якісних прикметників, які теж мають позитивні характеристики. Дієслова зберігати та купувати передають значення основних функцій, реалізувати які допоможе банк. А саме питання надійного збереження заощаджених коштів та зручного користування ними є актуальними для кожного, отже, банк відповідає запитам своїх клієнтів. Усі слова розглядуваної реклами ProCreditBanky наділені сугестивними властивостями.

Огляд рекламних слоганів засвідчив, що рекламісти, намагаючись привабити клієнта, нерідко використовують мовні одиниці з національно-культурним компонентом: географічні назви, не пов'язані з Україною, імена всесвітньо відомих особистостей, назви загальновідомих торгових марок i т. ін. У рекламі банків простежується часте використання краєзнавчої лексики. Так, слоган Кредобанку переконує:

Польський досвід. Украӥнський успіх. Свропейське майбутнє.

У пересічного українця сформована думка, що європейське завжди краще, що це те, до чого він прагне. Українські банки вже встигли дещо дискредитувати себе, тому зараз люди більше довіряють саме неукраїнським банкам, а, наприклад, таким, що мають польський досвід, тобто є стабільнішими. Отже, думка споживача реклами спрацьовує приблизно так: якщо скористатися послугами банку 3 польським досвідом, то й в Україні можна вигідно вкладати гроші та успішно провадити різні фінансові операції. А робити це заохочує словосполучення український успіх.

Банк Форум стверджує: Бізнес по-німецьки.

Споживач, зрозуміло, асоціює все німецьке 3 надійним та якісним, а отже, йому хочеться скористатися послугами фірми, яка працюватиме чітко - по-німецьки. Іменник бізнес наштовхує на думку про те, що саме банк допоможе вдало розгорнути підприємницьку діяльність, яка стане джерелом збагачення.

Банк БТА під зображенням дівчини у вінку 3 квітів подає 
слоган: Вирушай на парад квітів до Амстердама.

Географічна назва покликана викликати в уяві потенційних клієнтів банку приємні асоціації та спонукати мріяти про досі незвідане - про Амстердам, куди можна потрапити, скориставшись послугами банку БТА.

Otpbank заохочує: Виграй поӥзду в Угорщину.

Для того, щоб у клієнта швидше спрацювала уява про перебування в королівській країні, подано зображення чоловіка в колоритному угорському національному однострої. Слоган розрахований на те, що людина сама додумає приблизно такий підтекст: саме Otpbank допоможе мені романтично провести час.

Рекламістові важливо, щоб споживач не лише отримав інформацію про банк, а й асоціював його 3 країнами, містами, які користуються авторитетом. Самі ж географічні назви в цьому разі виступають ніби гарантом якості та надійності, часто й респектабельності, або ж, спокушаючи до романтичних подорожей, спонукають скористатися послугами банку. Отже, лінгвокраїнознавча лексика теж має притягувальну силу. Загалом же будь-які слова, що здатні викликати довіру, позитивну реакцію, можна вважати привабливими.

Ми виявили, що в рекламі здебільшого одночасно функціонують різні слова, що мають на меті привабити споживача. Так, в останніх наведених прикладах слоганів спостерігаємо вживання дієслів наказового способу вирушай, виграй, які виразно спонукають до дії. А пропущений займенник $m u$, який легко можна відновити, уможливлює псевдодіалог зі споживачем. Особові та присвійні займенники приваблюють того, хто сприймає рекламу. Слова Вам, для Вас, Тобi, Bam, Твій, Наш вказують на те, що запропонована інформація стосується людини особисто, а не якоїсь абстрактної аудиторії.

Наші спостереження свідчать, що рекламісти, намагаючись психологічно вплинути на споживача, вдаються й до пріоритетів суспільства. Так, останнім часом у зв'язку з політичними подіями дещо змістилися акценти в цінностях суспільства: зріс престиж українського патріотизму, популярною стала підтримка й пропаганда української національної ідеї. Реклама банків одразу відреагувала на такі суспільні порухи. Приватбанк на кредитній картці жовто-синього кольору подає напис: Слава Украӥні! Героям слава!. Інших слів узагалі немає. Але цей свого роду рекламний слоган ніби засвідчує:

(ㄱ Л. І. Конюхова, 2016. 
«Українці, ми з вами, ми за Вас. Можете нам довіряти».

Подібно рекламує свої послуги й Альфа-банк. На тлі неба й просторів України подано напис: 3 днем народження, Украӥно. Інша реклама цього ж банку пропонує слоган: Майбутнє Украйни у твойх руках.

Банк «Хрещатик» під зображенням неба й колосся пшениці розташував слоган: Вірю в Україну. Для переконливості цей напис відтінено зображенням жовто-синьої стрічки.

Банк «Надра» запропонував свою рекламу в короткометражному фільмі «Я люблю Україну». Сама назва фільму, яку подано на тлі карти України, використана у фільмі патріотична композиція Олександра Пономарьова «Заспіваймо пісню про Україну», вислови творців фільму на кшталт: Банк «Надра» - цее банк кожної родини є рекламою проукраїнськості банку. Засвідчивши свою позицію у ставленні до України, банк спонукає українського споживача довіряти своїй установі та скористатися іiї послугами.

Гадаємо, що використання в рекламі національної символіки й словесне вираження підтримки України спонукає споживачів банківських послуг повірити в порядність банківської установи, адже вона теж переймається проблемами України, любить Україну, а значить, підтримає й пересічних українців.

Наші спостереження засвідчили, що особливостями сугестії слоганів реклами банківських послуг є використання слів, які здатні навіяти споживачеві думку про престиж та надійність банку. Такими словами є якісні прикметники найвищого ступеня порівняння або такі, що передають позитивні характеристики рекламованого, іменники, що $\epsilon$ назвами суспільних пріоритетів, дієслова наказового способу, здатні спонукати до дії, особові та присвійні займенники, які ніби наближують банківську установу до споживача ії послуг, краєзнавча лексика.

У проаналізованих слоганах банківських послуг здебільшого немає чітких директив, а слова, використані із сугестивною метою, сприймаються невимушено, непомітно, вони просто «падають» у підсвідомість: людина не сприймає цих слів як якусь інструкцію, вона вважає, що сама приймає рішення скористатися послугою банку. Таке навіювання думки вважаємо непрямим. Непряме або опосередковане навіювання організовано так, що інформація сугестії подається в замаскованому вигляді. Відповідний добір мовних засобів сприяє 
неусвідомленому, непомітному, мимовільному засвоєнню інформації. Дослідник сугестогенних інновацій рекламних повідомлень В. Лученко зазначає: «М'які форми непрямого навіювання рідко натрапляють на опір сугеренда. Непряме навіювання дуже часто може бути мимовільним. Воно є звичайним компонентом буденного спілкування» [9]. Воно є невимушеним, непомітним, а тому й дуже прийнятним для реклами банків, адже вподобання та особливості поведінки людини часто продиктовані навіюванням, яке не усвідомлюється.

\section{Література}

1. Барт Р. Война языков. Избранные работы : Семиотика: поэтика / Р. Барт. - М. : Прогресс, 1994. - 616 с.

2. Павлюк Л. Знак символ-міф у масовій комунікації / Л. Павлюк. - Львів : ПАІС, 2006. $-120 \mathrm{c}$.

3. М'яснянкіна Л. Експресивність рекламного тексту / Л. М'яснянкіна // Українська журналістика в контексті доби : Матеріали всеукраїнської практичної конференції. - Львів, 2004. - С. 394-396.

4. Фурманкевич Н. Реклама: культура мови та мовна норма. Творчі та організаційні особливості функціонування сучасного медійного простору / Н. Фурманкевич // Збірник наукових праць. - Тернопіль-Львів, 2008. - Т. 2.

5. Лученко В. Суггестия в рекламе / В. Лученко // Политика. - 10 марта 2009 г. Стаття надійшла до редакиії 23.11.2015 p. 